\title{
Oligochaeta (Annelida: Clitellata) in the Juruena River, MT, Brazil: species indicators of substrate types
}

\author{
Guilherme Rossi Gorni ${ }^{1}$, Nathalie Aparecida de Oliveira Sanches ${ }^{2}$, Vanessa Colombo-Corbi ${ }^{1 *} \mathbb{\&}$ \\ Juliano José Corbi ${ }^{3}$ \\ ${ }^{1}$ Centro Universitário de Araraquara, Programa de Pós Graduação em Desenvolvimento Regional \\ e Meio Ambiente, Araraquara, SP, Brasil \\ ${ }^{2}$ Centro Universitário de Araraquara, Araraquara, SP, Brasil \\ ${ }^{3}$ Universidade de São Paulo, São Carlos, SP, Brasil \\ *Corresponding author: Vanessa Colombo-Corbi, e-mail:vanessacolombo25@yahoo.com.br
}

GORNI G. R., SANCHES N. A. O., COLOMBO-CORBI V., CORBI J. J. Oligochaeta (Annelida: Clitellata) in the Juruena River, MT, Brazil: species indicators of substrate types. Biota Neotropica. 18(4): e20180566. http://dx.doi.org/10.1590/1676-0611-BN-2018-0566

\begin{abstract}
Oligochaeta assemblages are important components in freshwater environments, where their abundance and composition may indicate aspects related to water quality and sediment. The lack of information about these communities in Brazilian aquatic environments, as well as the application of native species as bioindicators of lotic environmental, stimulated the conception of this paper. Thus, the aim was to study the community of aquatic Oligochaeta in selected stretches of the Juruena River (MT), thereby generating grounds for future environmental monitoring action in lotic ecosystems. For this purpose, samples were analyzed at bimonthly intervals during the period from January to November 2009, in stretches of the Juruena River (Amazon River Basin) located in the State of Mato Grosso (MT). Two methods were used to collect the organisms: a) "D" network in small clusters of fixed macrophytes in the sediment on the river banks; and b) Ekman-Birge dredge in fine sediment. Preliminary results were 584 organisms distributed in 22 taxa. Of these, 22 valid species were identified. This number corresponds to approximately $25 \%$ of the aquatic oligochaete species registered in Brazil. Of these species, Limnodrilus hoffmeisteri, Dero nivea and Pristina rosea can be associated with organic enrichment conditions and/or some level of environmental degradation.
\end{abstract}

Keywords: Freshwater oligochaetes, bioindicators, lotic environments, freshwater environments.

\section{Oligochaeta (Annelida: Clitellata) do Rio Juruena, MT, Brasil: espécies indicadoras em diferentes substratos}

Resumo: Comunidades de oligoquetos constituem importante componente em ambientes de água doce, onde sua abundância e composição podem indicar aspectos relacionados à qualidade da água e do sedimento. A carência de informações sobre estas comunidades em ambientes aquáticos brasileiros, bem como a aplicação de espécies nativas como bioindicadores de ambientes lóticos estimularam o desenvolvimento do presente trabalho. Assim, o objetivo foi estudar a comunidade de oligoquetos aquáticos em trechos selecionados do Rio Juruena (MT), gerando subsídios para futuras ações de monitoramento ambiental em ecossistemas lóticos. Métodos: Para isso foram analisadas amostras efetuadas em intervalos bimestrais durante o período de janeiro a novembro 2009, em trechos do Rio Juruena (Bacia Hidrográfica do Rio Amazonas) localizado no Estado de Mato Grosso (MT). Para coleta dos organismos foram utilizados dois métodos: a) rede em " $\mathrm{D}$ ” em pequenos agrupamentos de macrófitas fixas no sedimento nas margens do rio; e b) draga Ekman-Birge em sedimento arenoso. Os resultados preliminares 584 organismos distribuídos em 22 táxons. Dentre estes, foram identificadas 22 espécies válidas. Esse número corresponde aproximadamente $25 \%$ das espécies de oligoquetos aquáticos registradas no Brasil. Destas espécies, Limnodrilus hoffmeisteri, Dero nivea e Pristina rosea podem ser associadas à condições de enriquecimento orgânico e/ou algum nível de degradação ambiental.

Palavras-chave: Oligoquetos aquáticos, bioindicadores, ambientes lóticos, ambientes de água doce. 


\section{Introduction}

Oligochaeta are some of the most abundant groups in continental aquatic macrofauna and play an important role in the process of decomposition and cycling of organic matter in freshwater ecosystems (Ragonha \& Takeda, 2014, Cesar \& Henry 2017). These organisms are found in almost all fresh aquatic environments (Cesar \& Henry 2017), living in sediment and water columns (Rodriguez \& Reynoldson 2011), and in association with other organisms (Corbi et al. 2004, Alves \& Gorni 2007, Gorni \& Alves 2007, Gorni \& Alves 2008, Oda 2015).

In addition, these worms have limited mobility and are influenced by the habitat characteristics in which they are found (Behrend et al. 2012). Thus, the richness and abundance of Oligochaeta is directly related to environmental variables (Marchese \& Drago 1999, Jablonska, 2014), such as availability of food resources (Martins \& Silveira, Alves 2011); dissolved oxygen (Dornfeld et al. 2006); type of substrate (Moretto et al. 2013); water temperature (Nascimento \& Alves 2009), thus being considered indicators of specific habitats.

However, although common in freshwater environments (Timm et al. 2001), knowledge about Oligochaeta fauna in Brazilian fresh waters is still fragmented and incomplete (Alves et al. 2008, Takeda et al. 2017). This lacuna is mainly due to the concentration of studies related to the spatial distribution of benthic invertebrate fauna, with emphasis on insect larvae (Roque \& Trivinho-Strixino 2001, Sanseverino \& Nessimian, 2001), the great extent of the still unexplored parts of the Brazilian hydrographic basins (Joly et al. 2011) and the low financial investment in scientific research in the country (Agostinho et al. 2005, Magurran 2011).

However, since the 1980s, taxonomic identification keys developed specifically for South America (Brinkhurst \& Marchese 1989) and Brazil (Righi 1984) encouraged new research on the Oligochaeta, addressing aspects of their ecology (Petsch et al. 2015, Rodrigues et al. 2016), their geographic distribution (Gorni \& Alves, 2008, Gomes et al. 2017), their composition in anthropologically disturbed environments (Behrend et al. 2012, Rosa et al. 2014) and their use as test organisms in ecotoxicological experiments (Corbi et al. 2015, Lobo \& Espindola 2016).

However, the lack of information about these organisms in Brazilian aquatic environments is still evident in many regions (Gomes et al. 2017), as well as the use of native species as bioindicators of the quality of the country's aquatic ecosystems. Thus, the main objective of this paper was to study the aquatic Oligochaeta community in selected stretches of the Juruena River (MT), providing information for future action of environmental monitoring in lotic ecosystems.

\section{Material and Methods}

\section{Study area}

For the analysis of the Oligochaeta assemblages, samples were analyzed at bimonthly intervals during the period from January to November 2009. For the regular samplings, five sites were selected from the Juruena River (Amazon River Basin), located in the State of Mato Grosso (MT) (Figure 1).

The region is demarcated by humid tropical climates to contrasting seasons. Regionally the rainy season has its beginning, usually in the

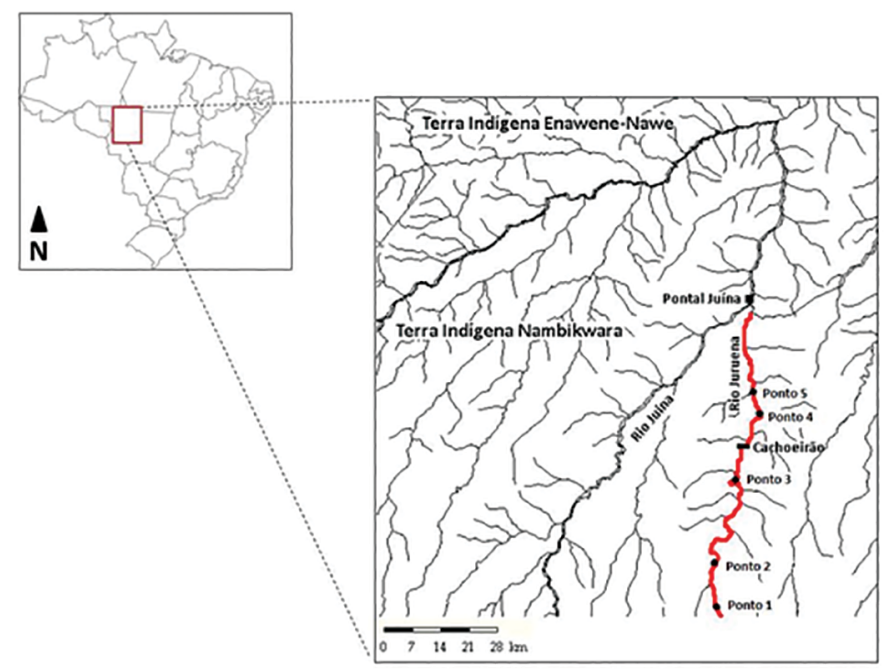

Figure 1. Map showing the location of the study area with highlight of the sampled section.

month of September until the month of April. From December to March are characterized by a increase in regional rainfall (Tardy, 1986). The basin is mainly sheltered by Ombrophilous Forest (Instituto Brasileiro de Geografia Estatística, 1992). In the upper portion of the basin, close to the Juruena, the vegetation is classified as "Cerrado". The soils in the basin are largely composed of red-yellow Acrisols (29\%), red-yellow Oxisols (27\%) and Arenosols (18\%) (Empresa Brasileira de Pesquisa Agropecuária, 1980).

The headwaters of Rio Juruena are situated at the Parecis Plateau, in a savanna ecosystem ("cerrado"). In this area the water is totally transparent and poor in nutrients ( $\mathrm{N}, \mathrm{P}$, and $\mathrm{Ca}$ ). Biochemical oxygen demand (BOD) and fecal coliform bacteria are low, demonstrating that anthropic contributions are insignificant. Macrophytes are not abundant and are distributed in discrete and sparse stands, sometimes covering a sand plateau onshore.

The collection sites were selected considering: i) prevailing habitats, ii) easy access, and iii) adequate sites for the use of benthic fauna samplers (details of the geographical location of the sites are shown in Table 1).

\section{Data collection}

The collection of organisms followed the methodology described by Dowing (1984) and Peckrasky (1984). Thus, two methods of collecting zoobenthos were used: a) the D-net sampler in small groups of fixed macrophytes on the river margin; and b) Ekman-Birge dredge in fine sediment to collected sediment and associated organisms.

The net, with $0.30 \mathrm{~m}$ mesh openings, was dragged $1.0 \mathrm{~m}$ by the macrophyte roots, making a capture area of $0.3 \mathrm{~m}^{2}$. The dredge, with an area of $0.0225 \mathrm{~m}^{2}$, was launched in locations close to the margins in depths of up to $3 \mathrm{~m}$. As an adopted procedure, two samples (replicas) were made with the net and dredge at each sampling site (a total of 50 sample units). Still at the sites, the collected samples were washed in a sieve with a mesh of $0.21 \mathrm{~mm}$ opening, fixed in $10 \%$ formalin and preserved in $70 \%$ alcohol. In the laboratory, the samples were washed again on a $0.021 \mathrm{~mm}$ mesh granulometric sieve. The organisms were screened in a WILD $^{\circledR}$ stereomicroscope with a maximal increase of 30 times. 
Oligochaeta as indicators of different substrate types

Table 1. Relative abundance of aquatic Oligochaeta species in Juruena River, and geographic coordinates of the sampling sites. $+: \leq 10 \% ; \diamond: 10<50 \%$; $\mathbf{m}: \geq 50 \%$.

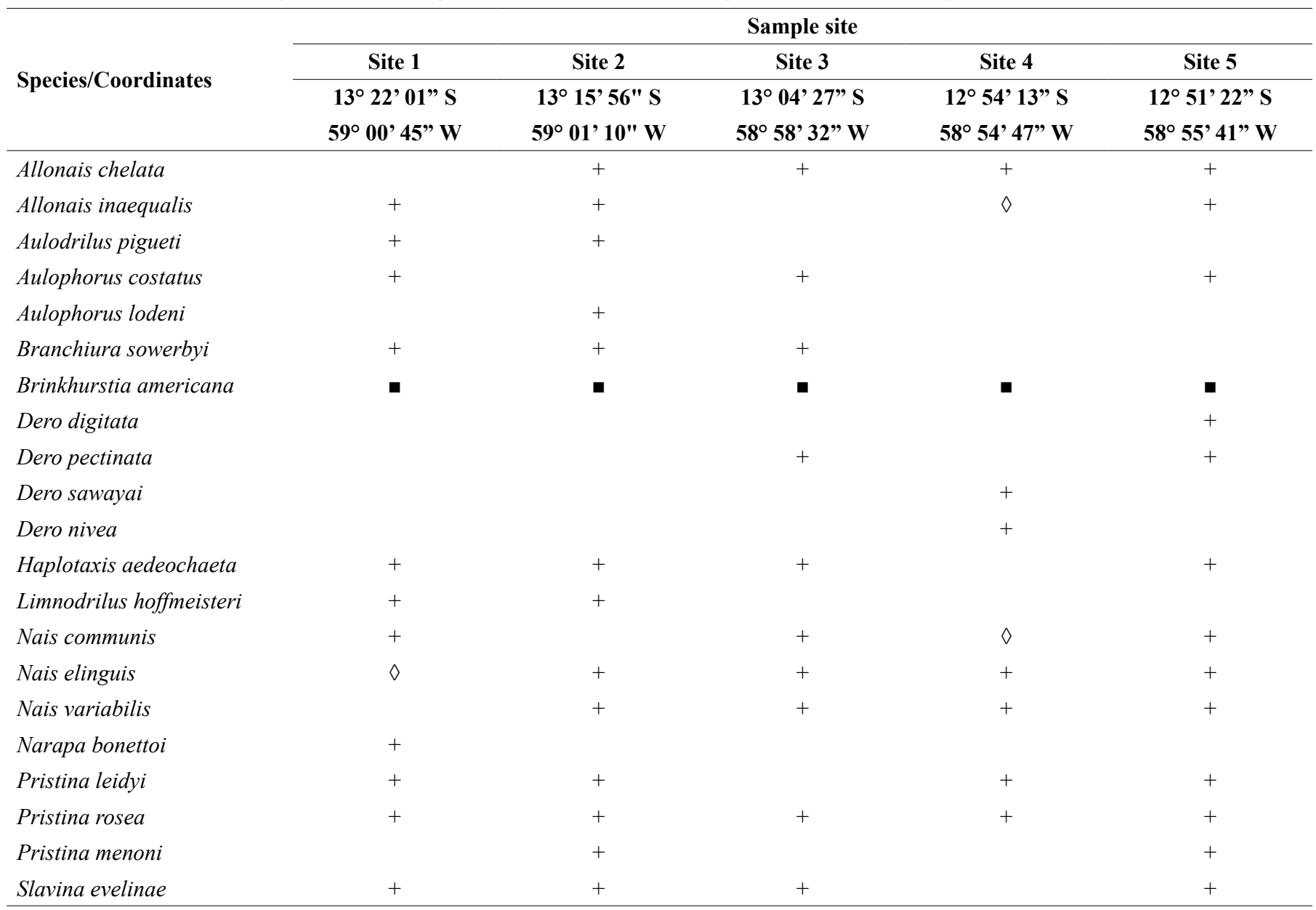

For the identification of Oligochaeta, taxonomic criteria adopted by Brinkhurst \& Jamieson (1971), Righi (1984), Brinkhurst \& Marchese (1989), Pinder \& Brinkhurst (1994) and Timm (2009) were followed. The list of species in synonymy was based on the catalog proposed by Christoffersen (2007).

All biological material identified was deposited in the Laboratory of Ecology and Aquatic Ecotoxicology (LEEA) linked to the Department of Hydraulics and Sanitation, School of Engineering of São Carlos, University of São Paulo.

In order to verify the sensitivity of the species to the different habitats, fixed macrophytes, mainly Podostemacean species on the river margin (collected with a D-net sampler) and fine sediment (EkmanBirge dredge) we applied Indicator Species Analysis (ISA) (Dufrene \& Legendre, 1997) $(\mathrm{alpha}=0.05)$. This analysis combines species relative abundance with their relative frequency of occurrence in the various groups of samplers. This analysis was made using the "indicspecies" package (De Caceres \& Legendre, 2009) in R software (R Core Team, 2017), with 10,000 permutations.

\section{Results}

A total of 584 organisms were identified in 22 valid species comprising 11 genera. This number corresponds to less than $1 \%$ of the aquatic species described in the world and approximately $1 / 4$ of the species registered in Brazil (Christoffersen 2007, Martin et al. 2008). The relative abundance of the Oligochaeta species are shown in Table 1. The specie Brinkhurstia americana showed a relative abundance greater than $50 \%$ of the total fauna in all the points sampled.

The Indicator Species Analysis (ISA) reveals five indicator species of fixed macrophytes (Aulophorus costatus, Dero pectinata, Dero digitata, Dero sawayai and Dero nivea), and four indicator species from fine sediment (Aulodrilus pigueti, Limnodrilus hoffmeisteri, Aulophorus lodeni and Narapa bonetoi) (Table 2).

\section{Discussion}

Listed below are the species, according to the nomenclature proposed by Timm (2017) with respective records from the Brazilian territory and ecological considerations.

\section{Allonais chelata}

Distribution: São Paulo: collected in urban streams by Alves and Lucca (2000) and associated with aquatic macrophytes (Alves \& Gorni 2007). Pernambuco: Gurjaú reservoir (Marcus 1944). Pará: Tapajós river, Trombetas river, São Manuel River, Cuminá river, Salgado lake, Cupari river by Marcus (1942) and by Du Bois-Reymond Marcus (1947, 
Colombo-Corbi, V. et al.

Table 2. Indicator Species in two collected habitats on the Juruena River (fixed macrophites and fine sediment). IV (\%): species indicator value obtained by 10,000 permutations (using the Monte Carlo Method).

\begin{tabular}{lcc}
\hline Taxa & Habitat & IV (\%) \\
\hline Aulodrilus pigueti & Fine sediment & 36.1 \\
Aulophorus costatus & Fixed macrophytes & 29.7 \\
Aulophorus lodeni & Fine sediment & 20.9 \\
Dero digitata & Fixed macrophytes & 20 \\
Dero pectinata & Fixed macrophytes & 25.1 \\
Dero sawayai & Fixed macrophytes & 20 \\
Dero nivea & Fixed macrophytes & 20 \\
Limnodrilus hoffmeisteri & Fine sediment & 36.1 \\
Narapa bonettoi & Fine sediment & 20.9 \\
\hline
\end{tabular}

1949a, 1949b). Amazonas: Grande Curuay lake by Marcus (1944) and Du Bois-Reymond Marcus (1944, 1947). Rio Grande do Sul: areas of irrigated rice fields (Sternert et al. 2012).

\section{Allonais inaequalis}

Distribution - São Paulo: associated with gastropods of the species Pomacea bridgesii (Gorni \& Alves 2006); associated with aquatic macrophytes (Alves; Gorni, 2007); and sponges of the species Metania spinata (Gorni \& Alves 2008a). It was also collected in the sediment of urban streams (Alves et al. 2006; Sanches et al. 2016). Rondônia: Cuniã lake by Gomes et al. (2017).

\section{Aulodrilus pigueti}

Distribution: Paraná: Patos Lake and Ivinhema River (MontanholiMartins \& Takeda 2001); in the Paraná River (Montanholi-Martins \& Takeda, 1999); in different floodplain habitats of the Paraná River (Ragonha \& Takeda, 2014, Petsch et al. 2015), in several reservoirs in the state of Paraná (Moretto et al. 2013); in the Paraná River, in the Ilha Grande National Park, between the states of Mato Grosso do Sul and Paraná (Ragonha et al. 2013); in tributaries of the Paraná River (Ragonha et al. 2014); in Ivinhema River and Baía River (Behrend et al. 2009) and Iguaçu River (Behrend et al. 2012). São Paulo: marginal lagoon of the Mogi-Guaçu River (Alves \& Strixino 2000, 2003). Mato Grosso do Sul: Negro River (Takeda et al. 2000). Piauí: collected in the Poti River by Sales et al. (2014). Rio Grande do Sul: in areas of irrigated rice fields (Sternert et al. 2012).

\section{Aulophorus costatus}

Distribution - Paraná: Patos Lake and Ivinhema tributary (Montanholi-Martins \& Takeda 2001). São Paulo: in the city of São Paulo (Marcus 1942, 1943); associated with the gastropod Pomaceae bridgesii (Gorni \& Alves 2006); associated with submerged macrophytes (Alves \& Gorni 2007); in reservoirs (Pamplin et al. 2005). Mato Grosso do Sul: Negro River (Takeda et al. 2000). Rondônia: Cuniã Lake by Gomes et al. (2017).

\section{Aulophorus lodeni}

Distribution - São Paulo: In the Infernão lagoon associated with the rhizosphere of the Scirpus cubensis macrophyte (Correia \& TrivinhoStrixino 1998), associated with the Scirpus, Eichhornia and Salvinia macrophytes in the Infernão lagoon by Trivinho-Strixino et al. (2000). Pará: in the Cupari River (Marcus 1942, Du Bois-Reymond Marcus 1947, 1949a, 1949b).

\section{Branchiura sowerbyi}

Distribution - São Paulo: Tietê River (Marcus 1942, 1943, Du Bois-Reymond Marcus, 1949a); in the Salto Grande eutrophic Reservoir (Dornfeld et al. 2006); Americana Dam by Pamplin et al. (2006); in the Monjolinho dam in the city of São Carlos (Fusari \& Fonseca-Gessner 2006); Tietê River reservoirs by Pamplin et al. (2005) and by Suriani et al. (2007) and in a marginal lagoon of the Mogi-Guaçu River (Alves \& Strixino 2000, 2003). Paraná: in several reservoirs in the state of Paraná (Moretto et al. 2013) and in the Iguaçu River (Behrend et al. 2012). Piauí: Poti River by Sales et al. (2014).

\section{Brinkhurstia americana}

Distribution - São Paulo: urban streams (Alves \& Lucca 2000, Alves et al. 2006; Sanches et al. 2016); in the Ribeirão das Anhumas reservoir (Corbi \& Trivinho-Strixino 2002); sediments of the Ponte Nova and Bariri reservoirs (Pamplin et al. 2005). Paraná: Ivinhema River and associated with the macrophyte Eichhornia azurea in the Patos lake (Montanholi-Martins \& Takeda 2001), in the Paraná River (Montanholi-Martins \& Takeda 1999); in Ivinhema River and Baía River (Behrend et al. 2009); in Iguaçu River (Behrend et al. 2012) and in several reservoirs in the state of Paraná (Moretto et al. 2013). Mato Grosso do Sul: Negro River (Takeda et al. 2000).

\section{Dero digitata}

Distribution - São Paulo: associated with the gastropod Pomaceae bridgesii (Gorni \& Alves 2006); associated with aquatic macrophytes (Alves \& Gorni,2007); in the Tietê River dam (Pamplin et al. 2005) and urban streams (Alves \&, Lucca 2000, Rosa et al. 2014). Mato Grosso do Sul: Negro River (Takeda et al. 2000). Pará: Tapajós, Cururu, Acará, São Manuel, Cupari and Juruena rivers and in the cities of Fordlandia, Belterra, Santarém and Itaituba (Marcus 1942, 1944, Du Bois-Reymond Marcus 1947, 1949a, 1949b). Amazonas: Grande Curuay Lake (Marcus 1944, Du Bois-Reymond Marcus 1944, 1947). Rondônia: Cuniã Lake (Gomes et al. 2017). Paraná: Iguaçu River (Behrend et al 2012); in different habitats of the Paraná River floodplain (Ragonha \& Takeda 2014), in several Paraná state reservoirs (Moretto 
et al. 2013) and associated with the macrophytes Hydrilla verticillata and Egeria najas collected in the Paraná River and Leopoldo Backwater (Behrend et al. 2013). Rio Grande do Sul: in areas of irrigated rice fields (Sternert et al. 2012).

\section{Dero pectinata}

Distribution - Paraná: Patos Lake, in the floodplain of the Paraná River (Montanholi-Martins \& Takeda 2001), in different floodplain habitats of the Paraná River (Ragonha \& Takeda 2014). São Paulo: was collected in reservoirs (Marcus 1943, Pamplin et al. 2005), in sediment of Ribeirão das Anhumas reservoir (Corbi \& Trivinho-Strixino, 2002); in an urban stream (Alves \& Lucca 2000, Alves et al. 2006) and in Tietê river reservoirs (Suriani et al. 2007). Mato Grosso do Sul: Negro River (Takeda et al. 2000).

\section{Dero sawayai}

Distribution: São Paulo: in streams (City of São Paulo) and Rio Claro by Marcus (1943), associated with gastropods (Gorni \& Alves, 2006), associated with submerged macrophytes (Alves \& Gorni 2007); associated with the sponge Metania spinata (Gorni, Alves, 2008a) and in urban impacted streams (Sanches et al. 2016). Paraná: associated with the macrophytes Hydrilla verticillata and Egeria najas collected in the Paraná River and the Leopoldo Backwater (Behrend et al. 2013), in the Iguaçu River (Behrend et al. 2012) and the Paraná River in the Ilha Grande National Park, between the states of Mato Grosso do Sul and Paraná (Ragonha et al. 2013); in different floodplain habitats of the Paraná River (Ragonha \& Takeda, 2014); in tributaries of the Paraná River (Ragonha et al. 2014); in Baía River in artificial substrates (Fujita et al. 2015) and Ivinhema and Baía rivers (Behrend et al., 2009). Minas Gerais: associated with decomposing leaves of Eichhornia azurea in Manacás Lake (Martins et al. 2011). Ceará: was found among individuals of the species Stolella agilis f. iheringi (Marcus 1942, 1943). Alagoas: was found in the city of Satuba, in an artificial tank (Marcus 1943, 1944). Pernambuco: São Francisco River (Marcus 1943, 1944). Rio Grande do Sul: in areas of irrigated rice fields (Sternert et al. 2012).

\section{Dero nivea}

Distribution: São Paulo: macrophyte rhizosphere (Correia \&Trivinho-Strixino 1998); marginal lagoon of the Mogi-Guaçu River (Alves \& Strixino 2000); associated with macrophytes in Infernão Lagoon (Trivinho-Strixinoet al. 2000 ); in the sediments of the Ribeirão das Anhumas reservoir (Corbi \& Trivinho-Strixino 2002), in Tietê river reservoirs (Pamplin et al. 200, Suriani et al. 2007); associated with gastropods (Gorni \& Alves 2006), in submerged macrophytes (Alves \& Gorni 2007); associated with the sponge Metania spinata (Gorni \& Alves 2008a) and in urban impacted streams (Sanches et al. 2016). Rio Grande do Sul: in areas of irrigated rice fields (Sternert et al. 2012). Rondônia: Cuniã Lake (Gomes et al. 2017).

\section{Haplotaxis aedeochaeta}

Distribution - Paraná: Detected in the Ivinhema River (MontanholiMartins; Takeda, 2001); Parana River (Montanholi-Martins \& Takeda 1999); in floodplain areas of the Parana River (Ragonha \& Takeda, 2014, Petsch et al. 2015), in Rio Ivinhema (Behrend et al. 2009), and in tributaries of the Paraná River (Ragonha et al. 2014).

\section{Limnodrilus hoffmeisteri}

Distribution: São Paulo: in cement tanks of the University of São Paulo, in streams of the Jardim Europa and Rio Tietê (Marcus 1942), in urban streams (Alves \& Lucca 2000, Alves et al. 2006, Rosa et al. 2014, Sanches et al. 2016); in marginal lagoon of the Mogi-Guaçu River, by Alves and Strixino (2000, 2003), in the Tietê River reservoir (Pamplin et al. 2005, Suriani et al. 2007), in the Salto Grande eutrophic Reservoir (Dornfeld et al. 2006), in the American Dam (Pampli et al. 2006), in the dam Monjolinho (Fusari \& Fonseca-Gessner 2006), in the Monjolinho reservoir (Fusari et al. 2006); in Monte Alegre Lake (Cleto-Filho \& Arcifa 2006), in streams of the Intervales State Park (Alves et al. 2008); Galharada and Serrote streams (Gorni \& Alves 2008b), in mesohabitats of Galharada stream (Gorni \& Alves 2012). Paraná: Iguaçu River (Behrend et al. 2012) and Paraná River, in the Ilha Grande National Park, between the states of Mato Grosso do Sul and Paraná (Ragonha et al. 2013); in the Paraná River (MontanholiMartins \& Takeda, 1999); in different floodplain habitats of the Paraná River (Ragonha \& Takeda 2014), in several reservoirs in the state of Paraná (Moretto et al. 2013); in the Paraná River tributaries (Ragonha et al. 2014) and Ivinhema and Baía rivers (Behrend et al. 2009). Rio Grande do Sul: Quadros lagoon, with muddy sediment and weakly brackish water (Marcus 1944). Minas Gerais: occurred in a stream of the Atlantic Forest (Rosa et al. 2015); in the São Pedro stream (Martins et al. 2008) and in an urban stream (Frizzera \& Alves 2012). Piauí: Poti River by Sales et al. (2014).

\section{Nais communis}

Distribution: São Paulo: associated with the sponge Ephydatia crateriformis (Marcus, 1943), the sponge Radiospongilla amazonenses (Corbi et al. 2005) and the sponge Metania spinata (Gorni \& Alves 2008a); associated with the macrophytes (Trivinho-Strixino et al. 2000, Alves \& Gorni 2007); sediment of urban streams (Alves \& Lucca 2000); associated with gastropods (Gorni \& Alves 2006, Martins \& Alves 2008); sediment of the Monjolinho River (Alves et al. 2006); associated with bryophytes of the genus Fissidens sp. and Philonotis sp. (Gorni \& Alves 2007); Campo do Meio and Galharada streams (Gorni; \& Alves 2008b, Gorni \& Alves 2012), streams of the Intervales Park (Alves et al. 2008); was detected in impacted urban streams (Rosa et al. 2014, Sanches et al. 2016). Minas Gerais: detected in first order streams of preserved areas (Rodrigues et al. 2013) and in an urban stream (Frizzera \& Alves 2012). Paraná: Paraná River, in the Ilha Grande National Park, between the states of Mato Grosso do Sul and Paraná (Ragonha et al. 2013), in the Iguaçu River (Behrend et al. 2012); in different floodplain habitats of the Paraná River (Ragonha \& Takeda 2014, Petsch et al. 2015); associated with the macrophytes Hydrilla verticillata and Egeria najas collected in the Paraná River and Leopoldo Backwater (Behrend et al. 2013); in tributaries of the Paraná River (Ragonha et al.,2014); Baía River, in artificial substrates (Fujita et al. 2015) and Ivinhema and Baía rivers (Behrend et al. 2009). Alagoas: was found by Marcus (1944) in the Paulo Afonso waterfall. Pará: near Belterra by Marcus (1942) and Du-Bois Reymond Marcus 1947, 1949a, 1949b).

\section{Nais elinguis}

Distribution - São Paulo: associated with the gastropod Pomaceae bridgesii (Gorni \& Alves 2006). 


\section{Nais variabilis}

Distribution - São Paulo: associated with Odonata larvae Elasmothemis cannacrioides and Mnesarete sp. (Corbi et al. 2004); associated with submerged aquatic macrophytes (Alves \& Gorni,2007); leaf litter of Galharada stream (Gorni \& Alves 2008b, Gorni \& Alves 2012) and was detected in impacted urban streams (Sanches et al. 2016). Minas Gerais: it was detected in first order streams of preserved areas (Rodrigues et al. 2013). Mato Grosso do Sul: Negro River (Takeda et al. 2000).

\section{Narapa bonettoi}

Distribution - Paraná: Ivinhema River (Montanholi-Martins; Takeda, 2001; Takeda et al. 2001); the Parana River (MontanholiMartins \& Takeda 1999); Ivinhema and Baía River (Behrend et al. 2009); in several reservoirs in the state of Paraná (Moretto et al. 2013), in floodplain areas of the Paraná River (Ragonha \& Takeda 2014, Petsch et al. 2015) and in tributaries of the Paraná River (Ragonha et al. 2014) São Paulo: Gouveia stream (Alves et al. 2006; Alves et al. 2006). Mato Grosso do Sul: Negro River (Takeda et al. 2000).

\section{Pristina leidyi}

Distribution - São Paulo: associated with colonies of Ephydatia crateriformis sponges, in the Araguá River sediment (Marcus 1943); (Alves \& Gorni 2007), associated with the Metania spinata sponge (Gorni \& Alves 2008a), associated with gastropods of the species Pomacea bridgesii (Gorni \& Alves 2006), associated with submerged macrophytes (Gorni \& Alves 2008b), in mesohabitats of the Galharada stream (Gorni \& Alves 2012) and was detected in impacted urban streams (Sanches et al. 2016). Paraná: in Ivinhema River (Behrend et al. 2009); Iguaçu River (Behrend et al. 2012); in tributaries of Paraná River (Ragonha et al. 2014) and Baía River, in artificial substrates (Fujita et al. 2015). Minas Gerais: occurred associated with decomposing leaves of Eichhornia azurea in Manacás Lake (Martins et al. 2011); in first order streams of preserved areas (Rodrigues et al. (2013) and associated with bryophytes (Rodrigues et al. 2016). Alagoas: in a creek of the city of Garça Torta (Du Bois-Reymond Marcus 1947). Pernambuco: São Francisco river (Marcus 1944). Rio Grande do Sul: in areas of irrigated rice fields (Stenert et al. 2012). Amazonas: near Humaitá by Marcus, (1943) and Du Bois- Reymond Marcus (1947, 1949a, 1949b).

\section{Pristina rosea}

Distribution - São Paulo: Pinheiros River and the campus of the University of São Paulo associated with bromeliads (Marcus 1943), in the Tietê River associated to the plant of the genus Calathea $\mathrm{sp}$. (Marcus 1944); in urban streams and a rural stream (Alves et al. 2006); in the Monjolinho reservoir, organically enriched (Fusari \& FonsecaGessner 2006); associated with bryophytes of the genus Fissidens sp. and Philonotis sp. (Gorni \& Alves 2007); in streams of low order of the Campos do Jordão State Park, characterized by cold waters, rapids and stony bed (Gorni \& Alves 2008b), in mesohabitats of the Galharada stream (Gorni \& Alves 2012) and was evidenced in impacted urban streams (Gorni et al., 2017). Minas Gerais: occurred in first-order streams of preserved areas (Rodrigues et al. 2013); associated with bryophytes (Rodrigues et al. 2016) and in a stream of the Atlantic Forest (Rosa et al. 2015). Pernambuco: city of Recife, in pools of water (Marcus 1944) and in Tegipió (Marcus 1943).

\section{Pristina menoni}

Distribution: São Paulo: urban streams (Alves et al. 2006, Sanches et al. 2016), associated to bryophytes of the genus Fissidens sp. and Philonotis sp. collected in the Jacaré Pepira River (Gorni \& Alves 2007). Paraná: Ivinhema River (Montanholi-Martins \& Takeda 2001). Minas Gerais: associated with bryophytes (Rodrigues et al. 2016). Rondônia: Cuniã Lake (Gomes et al. 2017).

\section{Slavina evelinae}

Distribution - São Paulo: in cement tanks of the University of São Paulo, associated to Ficus elastica (Marcus 1942); Canindé lake (Marcus 1944), macrophyte rhizosphere (Correia \&Trivinho-Strixino 1998), in the sediment of the Ribeirão das Anhumas reservoir (Corbi \& Trivinho-Strixino 2002), in the Tietê river reservoir sediment (Pamplin et al. 2005, Suriani et al. 2007); in submerged macrophytes (Alves \& Gorni 2007) and was evidenced in impacted urban streams (Sanches et al. 2016). Paraná: in Ivinhema and Baía rivers (Behrend et al. 2009); Paraná River, between the states of Mato Grosso do Sul and Paraná (Ragonha et al. 2013); in different floodplain habitats of the Paraná River (Ragonha \&Takeda 2014); in the Iguaçu River (Behrend et al. 2012); associated with the macrophytes Hydrilla verticillata and Egeria najas collected in the Paraná River and the Leopoldo Backwater (Behrend et al. 2013); found in floodplain areas of the Paraná River (Petsch et al. 2015) and in the Paraná River tributaries (Ragonha et al. 2014). Ceará: associated with bryozoans of the species Stolella agilis (Marcus 1942). Rio Grande do Sul: in areas of irrigated rice fields (Stenert et al. 2012). Mato Grosso do Sul: Negro River (Takeda et al. 2000). Minas Gerais: urban streams (Frizzera \& Alves 2012). Pernambuco: Near São Bartolomeu (Marcus 1942, 1943). Pará: in several rivers of the state (Marcus 1942, Du Bois-Reymond Marcus 1947, 1949a, 1949b).

Based on species distribution patterns and habitat preference (ISA) in the Juruena River, we concluded that Dero species are associated with marginal regions of aquatic ecosystems, mainly occurring as aquatic macrophytes. This condition demonstrates the susceptibility of this species group to samplers such as D-net. Limnodrilus hoffmeisteri, Aulodrilus pigueti, Narapa bonettoi and Aulophorus lodeni were related with depositional zones, where fine sediments occur. L. hoffmeisteri are also registered as being associated to organic enrichment conditions and/or some degree of environmental degradation.

Thus, in order to increase the efficiency of future environmental quality monitoring programs carried out in the region, cautious monitoring of these species in other parts of the Amazon River Basin is advisable.

\section{Acknowledgements}

We thank to Profa. Marlene Sofia Arcifa Froehlich. The São Paulo State Research Aid Foundation (FAPESP) and National Foundation for the Development of Private Higher Education (FUNADESP) for financial support and grants.

\section{Author Contributions}

Guilherme Rossi Gorni: Substantial contribution in the concept and design of the study; Contribution to data analysis and interpretation; 
Contribution to manuscript preparation; Contribution to critical revision, adding intelectual content.

Nathalie Aparecida de Oliveira Sanches: Contribution to data collection; Contribution to manuscript preparation.

Vanessa Colombo-Corbi: Contribution to manuscript preparation; Contribution to critical revision, adding intelectual content.

Juliano José Corbi: Contribution to data analysis and interpretation; Contribution to manuscript preparation; Contribution to critical revision, adding intelectual content.

\section{Conflicts of interest}

The author(s) declare(s) that they have no conflict of interest related to the publication of this manuscript.

\section{References}

AGOSTINHO, A. A., THOMAZ, S.M. \& GOMES, L.C. 2005. Conservação da biodiversidade em águas continentais do Brasil. Megadiversidade 1 (1): 70-78.

ALVES, R.G. \& GORNI, G.R. 2007. Naididae species (Oligochaeta) associated with submersed aquatic macrophytes in two reservoirs (São Paulo, Brazil). Acta Limnol. Bras. 19 (4): 407-413.

ALVES, R.G. \& STRIXINO, G. 2000. Distribuição espacial de Oligochaeta do sedimento de uma lagoa marginal do rio Mogi-Guaçu-SP. Iheringia, Sér. Zool. 88: 173-180.

ALVES, R.G. \& STRIXINO, G. 2003. The sampling of benthic macroinvertebrates using two different methods: Waiting trays and an Ekman collector. Acta Limnol. Bras. 15 (3): 1-6.

ALVES, R.G. \& LUCCA, J.V. 2000. Oligochaeta (Annelida: Clitellata) como indicador de poluição orgânica em dois córregos pertencentes à Bacia do Ribeirão do Ouro Araraquara (São Paulo-Brasil). Braz. J. Ecol. 4 (1-2): 112-117.

ALVES, R.G.; MARCHESE, M.R. \& ESCARPINATI, S.C. 2006. Oligochaeta (Annelida, Clitellata) in lotic environments in the State of São Paulo, Brazil. Iheringia, Sér. Zool. 96 (4): 431-435.

ALVES, R.G.; MARCHESE, M.R. \& MARTINS, R.T. 2008. Oligochaeta (Annelida, Clitellata) of lotic environments at Parque Estadual Intervales (São Paulo, Brazil). Biota Neotrop. 8 (1): 69-72.

BEHREND, R. D. L.; FERNANDES, S.E.P.; FUJITA, D.S. \& TAKEDA, A.M. 2009. Eight years of monitoring aquatic Oligochaeta from the Baía and Ivinhema Rivers. Braz. J. Biol. 69 (2): 559-571.

BEHREND, R.D.L., TAKEDA, A.M., GOMES, L.C. \& FERNANDES, S.E.P 2012. Using Oligochaeta assemblages as na indicator of environmental changes. Braz. J. Biol. 72 (4), 873-884.

BEHREND, R.D.L., TEIXEIRA, M.C., FERNANDES, S.E.P., CAMARGO, J.C., ROSIN, G.C. \& TAKEDA, A.M. 2013. Effects of a native and a non-native macrophyte species of Hydrocharitaceae on Chironomidae and Oligochaeta assemblages structure. Acta Sci. 35 (3): 351-358.

BRINKHURST, R.O. \& JAMIESON, B.G.M. 1971. Aquatic Oligochaeta of the world. University of Toronto Press, Toronto.

BRINKHURST, R.O. \& MARCHESE, M.R. 1989. Guia para la indentificacion de Oligoquetos aquáticos continentales de Sud y Centroamerica. Asociación de Ciencias Naturales del Litoral, Santa Fé.

DE CACERES, M. \& LEGENDRE, P. 2009. Associations between species and groups of sites: indices and statistical inference. Ecology 90 (12): 3566-3574.

CESAR, D. A. S. \& HENRY, R. 2017. Is similar the distribution of Chironomidae (Diptera) and Oligochaeta (Annelida, Clitellata) in a river and a lateral fluvial area? Acta Limnol. Bras. 29 (8).

CHRISTOFFERSEN, M.L. 2007. A catalogue of aquatic microdrile oligochaetes (Annelida: Clitellata) from South America. Acta Hydrobiol Sin. 31, 59-86.
CLETO-FILHO, S.E.N. \& ARCIFA, M.S. 2006. Horizontal distribution and temporal variation of the zoobenthos of a tropical Brazilian lake. Acta Limnol. Bras. 8 (4): 407-421.

CORBI, J.J., GORNI, G.R. \& CORREA, R.C. 2015. An evaluation of Allonais inaequalis Stephenson, 1911 (Oligochaeta: Naididae) as a toxicity test organism. Ecotoxicol. Environ. Contam. 10 (1): 7-11.

CORBI, J.J. \& TRIVINHO-STRIXINO, S. 2002. Spatial and bathymetric distribution macrobenthic fauna of the Ribeirão das Anhumas reservoir (Américo Brasiliense-SP, Brasil). Acta Limnol. Bras. 10 (1): 37-47.

CORBI, J.J., JANCSO, M.A., TRIVINHO-STRIXINO, S. \& FRAGOSO, E.N. 2004. Occurence of Oligochaeta living on larvae of Odonata from Ipeúna (São Paulo state, Brazil. Biota Neotrop. 4 (2): 1-3.

CORBI, J.J.; TRIVINHO-STRIXINO, S. \& ALVES, R.G. 2005. Records of oligochaetes in freshwater sponges, on bryozoans and on colonial hydrozoans from Brazil. Braz. J. Biol. 65 (1): 187-188.

CORREIA, L.C.S. \& TRIVINHO-STRIXINO, S. 1998. Macroinvertebrados da Rizosfera de Scirpus cubensis na lagoa do Infernão (Estação Ecológica de Jataí - SP): Estrutura e função. Acta Limnol. Bras. 10 (1): 37-47.

DORNFELD, C.B., ALVES, R.G., LEITE, M.A. \& ESPÍNDOLA, E.L.G. 2006. Oligochaeta in eutrofic reservoir: the case of Salto Grande reservoir and their main affluent (Americana, São Paulo, Brazil). Acta Limnol. Bras. 18 (2): 189-197.

DOWNING, J.A. 1984. Sampling the Benthos of Standing Waters. In A Manual on Methods for the Assessment of Secondary Productivity in Fresh Waters (J.A Downing \& F.H.Rigler, eds.). 2 ed. Blackwell Scient., London, p. 87-130.

DU BOIS-REYMOND MARCUS, E. 1944. Notes on fresh-water Oligochaeta from Brazil. Comun. Zool. Mus. Hist. Nat. Montevideo 1, 1-8.

DU BOIS-REYMOND MARCUS, E. 1947. Naidids and tubificids from Brazil. Comun. Zool. Mus. Hist. Nat. Montevideo 2 (44), 1-20.

DU BOIS-REYMOND MARCUS, E. 1949a. Further notes on naidids and tubificids from Brazil. Comun. Zool. Mus. Hist. Nat. Montevideo 51 (3), 1-15.

DU BOIS-REYMOND MARCUS, E. 1949b. A new tubificid from the Bay of Montevideo. Comun. Zool. Mus. Hist. Nat. Montevideo 56(3), 1-6.

DUFRÊNE, M. \& P. LEGENDRE. 1997. Species assemblages and indicator species: the need for a flexible asymmetrical approach. Ecol Monogr. 67: 345-366.

FRIZZERA, G.L. \& ALVES, R.G. 2012. The influence of taxonomic resolution of Oligochaeta on the evaluation of water quality in an urban stream in Minas Gerais, Brazil. Acta Limnol. Bras. 24 (4): 408-416.

FUJITA, D. S., TAKEDA, A. M., COUTINHO, R. \& FERNANDES, F. C. 2015. Influence of antifouling paint on freshwater invertebrates (Mytilidae, Chironomidae and Naididae): density, richness and composition. Braz. J. Biol. 75 (4): 70-78.

FUSARI, L.M. \& FONSECA-GESSNER, A.A. 2006. Environmental assessment of two small reservoirs in southeastern Brazil, using macroinvertebrate community metrics. Acta Limnol. Bras. 18 (1): 89-99.

GOMES, D. F., SANCHES, N. A. O., SAHM, L. H. \& GORNI, G. R. 2017. Aquatic oligochaeta (Annelida: Clitellata) in extractive reserve Lake Cuniã, Western Brazilian Amazon. Biota Neotrop. 17 (1): 1-7.

GORNI, G. R. \& ALVES, R.G. 2008a. Naididae species (Annelida: Oligochaeta) associated with the sponge Metania spinata (Carter, 1881) (Porifera: Metaniidae) from a southeastern reservoir. Acta Limnol. Bras. 20 (3): 261-263.

GORNI, G.R. \& ALVES, R.G. 2006. Naididae (Annelida, Oligochaeta) associated with Pomacea bridgesii (Reeve) (Gastropoda, Ampullaridae) Rev. Bras. Zool. 23 (4): 1059-1061,

GORNI, G.R. \& ALVES, R.G. 2007. Naididae (Annelida, Oligochaeta) associated with briophytes in Brotas, State of São Paulo, Brazil. Rev. Bras. Zool. 24 (2): 518-519,

GORNI, G.R. \& ALVES, R.G. 2008b. Oligochaeta (Annelida: Clitellata) em córregos de baixa ordem do Parque Estadual de Campos do Jordão (São Paulo - Brasil). Biota Neotrop. 8 (4): 161-165. 
GORNI, G.R. \& ALVES, R.G. 2012. Oligochaetes (Annelida, Clitellata) in a neotropical stream: a mesohabitat approach. Iheringia 102 (1): 106-110.

JABLONSKA, A. 2014. Oligochaete communities of highly degraded urban streams in Poland, Central Europe. North-West. J. Zool. 10 (1): 74-82,

JOLY, C. A., HADDAD, C. B., VERDADE, L., OLIVEIRA, M. C., BOLZANI, V. S. \& BERLINCK, R. 2011. Diagnóstico da pesquisa em biodiversidade no Brasil. Revista USP 89, 114-133.

LOBO, H. \& ESPÍNDOLA, E. L. G. 2016. Branchiura sowerbyi reared in two sediments for ecotoxicological bioassays, Ecotoxicol. Environ. Contam. 11 (1): 11-14.

MAGURRAN, A. E. 2011. Medindo a diversidade biológica. Editora UFPR, Paraná.

MARCHESE, M. \& DRAGO, I.E. 1999. Use of benthic macroinvertebrates as organic pollution indicators in lotic environments of Paraná River drainage basin. Pol. Arch. Hydrobiol. 46 (3-4): 233-255.

MARCUS, E. 1942. Sobre algumas Tubificidae do Brasil. Bol. Fac. Filos. Ciên. Let. Univ. S. Paulo 25 (6): 153-228.

MARCUS, E. 1943. Sobre Naididae do Brasil. Bol. Fac. Filos. Ciên. Let. Univ. S. Paulo 32 (7): 3-247.

MARCUS, E. 1944. Sobre Oligochaeta límnicos do Brasil. Bol. Fac. Filos. Ciên. Let. Univ. S. Paulo 43 (8): 5-135.

MARTIN, P.; MARTÍNEZ-ANSEMIL, E.; PINDER, A.; TIMM, T. \& WETZEL, M.J. 2007. Global diversity of oligochaetous clitellates ("Oligochaeta", Clitellata) in freshwater. In Freshwater animal diversity assessment (E.V. Balian, C. Lévêque, H. Segers \& K.. Martens eds.). Developments in Hydrobiology, vol 198. Springer, Dordrecht, p. 117-127.

MARTINS, R.T., SILVEIRA, L.S. \& ALVES, R.G.. 2011. Colonization by oligochaetes (Annelida: Clitellata) in decomposing leaves of Eichhornia azurea (SW.) Kunth (Pontederiaceae) in a neotropical lentic system. Ann. Limnol. 47: 339-346.

MARTINS, R.T. \& ALVES, R.G. 2008. Occurrence of Naididae (Annelida: Oligochaeta) from three gastropod species in irrigation fields in southeastern Brazil. Biota Neotrop. 8 (3): 255-257.

MARTINS, R.T.; STEPHAN, N.N.C. \& ALVES, R.G. 2008. Tubificidae (Annelida: Oligochaeta) as an indicator of water quality in an urban stream in southeast Brazil. Acta Limnol. Bras. 20 (3): 221-226.

MONTANHOLI-MARTINS, M.C. \& TAKEDA, A.M. 1999. Communities of benthic oligochaetes in relation to sediment structure in the Upper Paraná River, Brazil. Stud. Neotrop. Fauna 34: 52-58.

MONTANHOLI-MARTINS, M.C. \& TAKEDA, A.M. 2001. Spatial \& temporal variations of oligochaetes of the Ivinhema River and Patos Lake in the Upper Paraná River Basin, Brazil. Hydrobiologia, 463 (1-3): 197- 205.

MORETTO, Y.; SIMÕES, N.R.; BENEDITO, E. \& HIGUTI, J. 2013. Effect of trophic status and sediment particle size on diversity and abundance of aquatic Oligochaeta (Annelida) in neotropical reservoirs. Ann. Limnol. 49 (1): 65-78.

NASCIMENTO, H.L.S. \& ALVES, R.G. 2009. The effect of temperature on the reproduction of Limnodrilus hoffmeisteri (Oligochaeta: Tubificidae). Zoologia 26 (1): 191-193,

ODA, F. H., PETSCH, D. K., RAGONHA, F. H., BATISTA, V. G., TAKEDA, A. M. \& TAKEMOTO, R. M. 2015. Dero (Allodero) lutzi Michaelsen, 1926 (Oligochaeta: Naididae) associated with Scinax fuscovarius (Lutz, 1925) (Anura: Hylidae) from Semi-deciduous Atlantic Rain Forest, southern Brazil. Braz. J. Biol. 75 (1): 86-90.

PAMPLIN, P.A.Z.; ALMEIDA, T.C.M. \& ROCHA, O. 2006. Composition and distribution of benthic macroinvertebrados in Americana Reservoir (SP, Brazil). Acta Limnol. Bras. 18 (2): 121-132.

PAMPLIN, P.A.Z.; ROCHA, O. \& MARCHESE, M. 2005. Riqueza de espécies de Oligochaeta (Annelida, Clitellata) em duas represas do Rio Tietê (São Paulo). Biota Neotrop. 5 (1): 1-8.
PECKARSKY, B.L. 1984. Sampling the Stream Benthos. In A Manual on Methods for the Assessment of Secondary Productivity in Fresh Waters (J.A Downing \& F.H.Rigler, eds.). 2 ed. Blackwell Scient., London, p. 131-160.

PETSCH, D.K.; RAGONHA, F.H.; GIMENEZ, B.C.G.; BARBOZA, L.G.A. \& TAKEDA, A.M. 2015. Partitioning beta diversity of aquatic Oligochaeta in different environments of a Neotropical floodplain. Acta Sci. Biol. Sci. 37 (1): 41.

PINDER, A.P. \& BRINKHURST, R.O. 1994. A Preliminary Guide to the Identification of the Microdrile Oligochaeta of Australian Inland Waters. Cooperative Research Centre for Freshwater Ecology, Albruy.

R CORE TEAM. 2017. R: A language and environment for statistical computing. R Foundation for Statistical Computing, Vienna, Austria. http://www.Rproject.org/ (last access in 19/04/2018)

RAGONHA, F.H., CHIARAMONTE, J.B., JUNIOR, H.M.F., CUNHA, E.R., BENEDITO, E. \& TAKEDA, A.M. 2013. Spatial distribution of aquatic Oligochaeta in Ilha Grande National Park, Brazil. Acta Sci. 35 (1): 63-70.

RAGONHA, F. H., PETSCH, D. K., ALVES, G. H. Z., SANTANA, H. S., MICHELAN, T. S., TAKEDA, A. M. 2014. Tributaries as richness source for Oligochaeta assemblage (Annelida) of Neotropical dammed river. Braz. J. Biol. 74 (4): 861-869.

RAGONHA, F.H. \& TAKEDA, A. M. 2014. Does richness of Oligochaeta (Annelida) follows a linear distribution with habitat structural heterogenety in aquatic sediments? J. Limnol. 73 (1): 146-156.

RODRIGUEZ, P. \& REYNOLDSON, T.B. 2011. The Pollution Biology of Aquatic Oligochaetes. Ed. Springer Science, London.

RIGHI, G. 1984. Manual de identificação de invertebrados límnicos do Brasil. $\mathrm{CNpq} /$ Coordenação Editorial, Brasília.

ROGRIGUES, L. F.T., LEITE, F.S. \& ALVES, R.G. 2013. Inventory and distribution of Oligochaeta (Annelida: Clitellata) in first-order streams in preserved areas of the state of Minas Gerais, Brazil. Biota Neotrop. 13 (1): 245-254.

RODRIGUES, L. F. T.; LEITE, F. S. \& ALVES, R. G. 2016. Influence of bryophyte biomass and organic matter quantity on the abundance and richness of oligochaetes in forest streams with different phytophysiognomies in southeastern Brazil. J. Limnol. 75 (2): 340-346.

ROQUE F.O. \&TRIVINHO-STRIXINO, S. 2001. Benthic macroinvertebrates in mesohabitats of diferent spatial dimensions in a first order stream. Acta Limnol. Bras. 13: 69-77.

ROSA, B. F. J. V.; MARTINS, R. T. \& ALVES, R. G. 2015. Distribution of oligochaetes in a stream in the Atlantic Forest in southeastern Brazil. Braz. J. Biol. 75 (1): 1-7.

ROSA, B.J.F.V.; RODRIGUES, L.F.T.; OLIVEIRA, G.S. \& ALVES, R.G. 2014. Chironomidae and Oligochaeta for water quality evaluation in an urban river in southeastern Brazil. Environ Monit Assess. 186 (11): 7771-7779.

SALES, P. C. L., RAGONHA, F. H., RODRIGUES, E. I., DEUS, M. S. M. LOPE, M. S. \&TAKEDA, A. M. 2014. Primeiros registros de espécies de Oligochaeta aquática (Annelida - Clitellata) do Estado Piaú (Nordeste Brasil), Arquivos do MUDI 18 (2): 1-4.

SANCHES, N.A.O.; SAHM, L.H. \&GOMES, D.F. 2016. Inventário de Oligochaeta (Annelida: Clitellata) em córregos urbanos de Bocaina-SP, Brasil. ReBraM 19 (1): 14-24.

SANSEVERINO, A.M. \&NESSIMIAN, J.L. 2001. Hábitats de larvas de Chironomidae (Insecta, Diptera) em riachos de Mata Atlântica no Estado do Rio de Janeiro. Acta Limnol. Bras. 13: 29-38.

STENERT; C.; MALTCHIK, L. \& ROCHA, O. 2012. Diversidade de invertebrados aquáticos em arrozais no Sul do Brasil. Neotrop. Biol. Conserv.7 (1): 67-77.

SURIANI, A.L., FRANÇA, R.S., PAMPLIN, P.A.Z., MARCHESE, M., LUCCA \&J.V. ROCHA, O. 2007. Species richness and distribution of oligochaetes in six reservoirs on Middle and Low Tietê River (SP, Brazil). Acta Limnol. Bras. 19 (4): 415-426. 
TAKEDA, A. M., PEREIRA, M. C. F. \& BARBOSA, F. A. R. 2000. Zoobenthos survey of the Pantanal, Mato Grosso do Sul, Brasil. Bull. Biol. Assess. Enginee. 18 (3): 49-55.

TAKEDA, A.M. 2001. Effect of hydraulics, bed load grain size and water factor on habitat and abundance of Narapa bonetoi Righi \& Varela, 1983 of the Upper Paraná River, Brazil. Oligochaeta community of alluvial Upper Paraná River, Brazil: spatial and temporal distribution (1987-1988). Hydrobiologia 463: 35-42.

TAKEDA, A. M., FUJITA, D. S., RAGONHA, F.H., PETSCH, D.K. \& MONTANHOLI-MARTINS, M.C. 2017. Oligochaeta (Annelida) de ambientes aquáticos continentais do Estado do Mato Grosso do Sul (Brasil), Iheringia, Sér. Zool. 107: 1-5.
TARDY, Y. 1986. Le Cycle de L'Eau - Climats, Paleoclimats et Géochimie Globale. Masson Editeurs, 338 p, Paris, France

TIMM, T. 2009. A guide to the freshwater Oligochaeta and Polychaeta of Northern and Central Europe. Lauterbornia 66: 1-235.

TIMM, T. 2017. Aquatic microdrile Oligochaeta (Annelida, Clitellata): New nominal taxa and combinations since 1984. Zootaxa 4282 (3): 401-452.

TIMM, T.; SEIRE, A.; PALL, P. 2001. Half a century of oligochaete research in Estonian running waters. Hydrobiologia 463: 223-234.

TRIVINHO-STRIXINO, S., CORREIA, L.C.S. \& SONODA, K. 2000. Phytophilous Chironomidae (Diptera) and other macroinvertebrates in the ox-bow Infernão Lake (Jataí Ecological Station, Luiz Antônio, SP, Brazil). Rev. Bras. Biol. 60 (3): 527-535. 